\title{
PENGARUH PROFITABILITAS, LIKUIDITAS, UKURAN PERUSAHAAN, PERTUMBUHAN PENJUALAN DAN DIVIDEND PAYOUT RATIO TERHADAP STRUKTUR MODAL (Studi pada Perusahaan Property dan Realestate yang terdaftar di BEI tahun 2013-2017)
}

\author{
Rahmadani'1), Rangga Putra Ananto'0), Wiwik Andriani' ${ }^{3)}$
}

Jurusan Akuntansi, Politeknik Negeri Padang

Email: rahmadaniak@gmail.com¹), rangga@pnp.ac.id ${ }^{2}$, wiwikandriani@pnp.ac.id ${ }^{3)}$

\begin{abstract}
This study aims to determine the effect of profitability, liquidity, firm size, sales growth, and dividend payout ratio on capital structure. The sampling technique uses purposive sampling method so that a sample of 28 property and realestate companies are listed on the Indonesia Stock Exchange during the 2013-2017 period. The type of data used is secondary data in the form of annual financial statements of property and realsetate companies in 2013-2017. Data analysis method used is multiple linear regression analysis using SPSS version 20. The results of this study indicate that partially profitability proxied by net profit margin (NPM) does not affect the capital structure, liquidity is proxied by the current ratio (CR) effect on the capital structure, the size of the company which is proxied by total assets (Ln TA) does not affect capital structure, sales growth that does not affect the capital structure, dividend payout ratio does not affect the capital structure. Simultaneously profitability, liquidity, company size, sales growth and dividend payout ratio affect the capital structure
\end{abstract}

Keywords: profitability, liquidity, company size, sales growth, dividend payout ratio, capital structure.

\begin{abstract}
ABSTRAK
Penelitian ini bertujuan untuk mengetahui pengaruh profitabilitas, likuiditas, ukuran perusahaan, pertumbuhan penjualan, dan dividend payout ratio terhadap struktur modal. Teknik pengambilan sampel menggunakan metode purposive sampling sehingga diperoleh sampel sebanyak 28 perusahaan property dan realestate yang terdaftar di Bursa Efek Indonesia selama periode 2013-2017. Jenis data yang digunakan yaitu data sekunder berupa laporan keuangan tahunan perusahaan property dan realsetate tahun 2013-2017. Metode analisis data yang digunakan adalah analisis regresi linear berganda dengan menggunakan aplikasi SPSS versi 20. Hasil penelitian ini menunjukkan bahwa secara parsial profitabilitas yang diproksi dengan net profit margin (NPM) tidak berpengaruh terhadap struktur modal, likuiditas yang diproksi dengan current ratio (CR) berpengaruh terhadap struktur modal, ukuran perusahaan yang diproksi dengan total aset (Ln TA) tidak berpangaruh terhadap struktur modal, pertumbuhan penjualan yang tidak berpengaruh terhadap struktur modal, dividend payout ratio tidak berpengaruh terhadap struktur modal.
\end{abstract}

Kata kunci: profitabilitas, likuiditas, ukuran perusahaan, pertumbuhan penjualan, dividend payout ratio, struktur modal. 


\section{Pendahuluan}

Perkembangan bisnis yang terus berkembang dan bertumbuh diiringi dengan banyak industri baru yang berdiri, menyebabkan persaingan bisnis juga semakin ketat (Eviani 2015). Untuk menghadapi ketatnya suatu persaingan dalam menjalankan suatu perusahaan harus mempunyai suatu tujuan yang jelas dan sudah ditentukan. Agar dapat mempertahankan suatu perusahaan dalam menghadapi ketatnya persaingan yang ada, maka oleh karena itu pihak manajemen harus dapat menemukan cara dan strategi untuk dapat bersaing dengan perusahaan lainnya.

Dalam mengoperasikan dan menjalankan suatu perusahaan pasti membutukan modal yang digunakan untuk mengembangkan usahanya sehingga dapat mencapai tujuan yang diinginkan. Dalam memenuhi modal usaha perusahaan dapat dilakukan dengan cara pendanaan baik secara internal maupun ekternal. Kebutuhan dana perusahaan dari sumber internal yaitu sumber dana yang dihasilkan sendiri dalam perusahaan, dapat berupa saldo laba, serta dari kegiatan operasional perusahaan. Sedangkan kebutuhan dana ekternal dapat berasal dari hutang atau pinjaman jangka pendek maupun jangka panjang (Wirasedana dan Abimanyu 2015).

Dalam memilih sumber dana maka perusahaaan harus memikirkan secara matang karena hal tersebut akan mempengaruhi struktur modal perusahaan. Oleh karena itu dalam suatu perusahaan pihak manajemen harus memperhatikan apakah sumber dana yang diperlukan oleh perusahaan dipenuhi dengan modal sendiri atau dengan hutang sehingga dapat menghasilkan struktur modal yang optimal dan keuntungan terhadap perusahaan. Struktur modal yang optimal adalah suatu kondisi dimana sebuah perusahaan dapat menggunakan kombinasi utang dan ekuitas secara ideal. Struktur modal yang optimal adalah struktur modal yang memaksimalkan harga saham atau nilai perusahaan dan sekaligus juga meminimumkan biaya modal rata-ratanya (Brigham \& Houston, 2011). Struktur modal yang optimal dapat berubah sepanjang waktu, yang dapat mempengaruhi adalah biaya modal rata-rata tertimbangan. Biaya modal rata-rata tertimbang merupakan biaya modal perusahaan yang terdiri dari saham, penggunaan hutang dan saldo laba.

Kemajuan dan kemunduran suatu perusahaan tergantung bagaimana pihak manajemen dalam mengelola perusahaan. Pengelolan struktur modal merupakan hal yang terpenting yang harus diperhatikan dalam suatu perusahaan karena tidak sedikit perusahaan mengalami kegagalan yang disebabkan karena terjadinya suatu persoalan dalam mengelola struktur modal. Struktur modal adalah perimbangan atau perbandingan antara modal asing (jangka panjang) dengan modal sendiri (Riyanto, 2011). Struktur modal baru dapat dikatakan baik jika adanya kombinasi antara hutang dan modal yang berfungsi untuk memaksimumkan harga saham (Mustanda dan Angelina 2016). Setiap sumber modal mempunyai suatu resiko dan jangka waktu sehingga dalam mengambil keputusan seorang manajemen harus selektif. Resiko yang akan dapat timbul dari sumber modal apabila pihak manajemen tidak selektif dalam memilih modal adalah resiko bisnis dan keuangan. Resiko bisnis merupakan ketidakpastian pada perkiraan pendapatan operasi perusahaan dimasa mendatang. Resiko bisnis dipengaruh oleh berapa faktor-faktor seperti variabilitas permintaan, variabilitas harga, variabilitas biaya input, kemampuan menyesuaikan harga jika ada perubahaan biaya dan tingkat penggunaan biaya tetap (Atmaja 2008). Sedangkan resiko keuangan merupakan risiko tambahan pada perusahaan akibat keputusan mengunakan hutang atau resiko yang ditimbulkan dari penggunaan hutang. 
Baik buruknya struktur modal perusahaan dapat dipengaruhi oleh beberapa faktor. Bagi suatu perusahaan penting untuk mengetahui faktor yang dapat mempengaruhi struktur modal, karena hal itu berhubungan dengan pihak manajemen dalam mengambil keputusan struktur modal yang tepat bagi kelangsungan hidup perusahaan. Adanya faktor-faktor yang mempengaruh strukur modal perusahaan menjadi hal yang penting sebagai pertimbangan dalam menentukan komposisi struktur modal perusahaan (Widati dan Farisa 2017). Banyak faktor yang dapat mempengaruhi keputusan manajemen dalam menentukan struktur modal perusahaan. Menurut Bringham dan Houstoon (2011) faktor-faktor yang dapat mempengaruhi struktur modal adalah stabilitas penjualan, struktur aset, leverage operasi, tingkat pertumbuhan, profitabilitas, pajak, kendali, sikap manajemen, sikap pemberi pinjaman dan lembaga pemeringkat, kondisi pasar, kondisi internal perusahaan dan fleksibilitas keuangan. Menurut Santono (2010) mengatakan bahwa faktor yang penting dalam menentukan struktur modal adalah seperti tingkat penjualan, struktur aset, tingkat pertumbuhan perusahaan, profitabilitas, variabel laba dan perlindungan.

Dalam pecking order theory juga mengatakan bahwa kebijakan dividen dan profitabilitas juga merupakan faktor yang mempengaruh struktur modal. Dalam pecking order theory dividend payout ratio merupakan bentuk dari kebijakan dividen yang mempengaruhi struktur modal. Struktur modal juga dapat di diukur menggunakan leverage, dimana faktor- faktor mempengaruhi terdiri dari ukuran perusahaan, peluang pertumbuhan, likuiditas, tangibilitas aset, usia perusahaan, nondabt tax shiel dan investasi (Ramlall, 2009 dalam Dewi dan Julianti 2016). Namun dalam penelitian ini hanya beberapa faktor akan diteliti yaitu profitabilitas, likuiditas, ukuran perusahaan, pertumbuhan penjualan dan dividend payout rasio karena dari sebelumnya masih banyak perbanyak perbedaan hasil, serta dilihat dari hasil penelitian sebelumnya faktor tersebut paling berpengaruh dalam struktur modal.

Di Indonesia, sektor property dan realestate merupakan salah satu sektor yang cukup stabil pertumbuhannya sekitar 20-30\% per tahun. Namun Pada tahun 2016 DPP Realestate Indonesia (REI) mencatat, pada triwulan ketiga 2016, seluruh sektor dan sub-sektor realestate di Indonesia mengalami pertumbuhan yang lambat yaitu di angka 3,7 persen dibandingkan tahun 2015. Padahal sebenarnya potensi pasar sektor properti cukup besar, karena didukung beberapa faktor. Hal ini dapat dilihat dari pertumbuhan penduduk Indonesia cukup signifikan. Pertumbuhan penduduk Indonesia saat ini mencapai 1,2 persen atau sekitar tiga juta jiwa setiap tahunnya. Dengan demikian, angka kebutuhan rumah pun akan terus meningkat setiap tahunnya. Berdasarkan data Badan Pusat Statistik pada tahun 2016, angka kebutuhan rumah atau backlog masih mencapai 11,4 juta unit. Meski pemerintah telah merecanangkan Program Nasional Sejuta Rumah setiap tahun, namun belum pernah tercapai sampai saat ini. Potensi berikutnya, yaitu diakibatkan ekspansi pembangunan lahan kosong. Baik itu dari ekspansi daratan ke wilayah sawah, kebun atau hutan, maupun ekspansi ke laut lewat proyek reklamasi. Hal ini disebakan karena penduduknya yang bertambah, maka perusahaan akan selalu melakukan diekspansi (Kompas.com, 11/7/2018).

Dari informasi diatas, penulis tertarik untuk melakukan penelitian mengenai pengaruh profitabilitas, likuiditas, ukuran perusahaa, pertumbuhan penjualan dan dividend payout ratio terhadap struktur modal pada perusahaan property dan realestate yang terdaftar di Bursa Efek Indonesia tahun 2013-2017. 


\section{Tinjauan Pustaka Dan Perumusan Hipotesis \\ Tinjauan Pustaka \\ Pecking Order Theory}

Dalam pecking order theory mengatakan bahwa perusahaan akan lebih dahulu menggunakan dana internal. Dalam teori menjelasakan secara spesifik perusahaan mempunyai urut-urutan dalam penggunaan dana. Dalam pecking order theory (Myers 2001 dalam Sari 2014) terdapat urutan dalam memilih sumber pendanaan, yaitu:

1. Perusahaan lebih memilih untuk menggunakan sumber dana dari dalam atau pendanaan internal daripada pendanaan eksternal. Dana internal tersebut diperoleh dari saldo laba yang dihasilkan dari kegiatan operasional perusahaan.

2. Apabila pendanaan eksternal diperlukan, maka perusahaan akan memilih pertama kali menerbitkan sekuritas yang paling aman, yaitu hutang yang paling rendah risikonya, turun ke hutang yang lebih berisiko, sekuritas hybrid seperti obligasi konversi, saham preferen, dan yang terakhir saham biasa.

3. Adanya kebijakan devidend yang konstan, hal ini menyababkan perusahaan akan menetapkan jumlah pembayaran deviden yang konstan, hal ini tidak terpengaruh seberapa besar perusahaan tersebut mengalami untung ataupun rugi.

4. Untuk mengantisipasi kekurangan persediaan kas karena adanya kebijakan dividen yang konstan dan fluktuasi dari tingkat keuntungan, serta kesempatan investasi, maka perusahaan akan mengambil portofolio investasi yang lancar tersedia.

\section{Trade off Theory}

Dalam trade off theory menyatakan bahwa rasio hutang yang optimal dapat ditentukan berdasarkan perbandingan atau perimbangan antara manfaat yang diperoleh dan biaya yang ditimbulkan akibat penggunaan hutang (Widati dan Farisa 2017). Tambahan hutang masih bisa dilakukan oleh perusahaan selama manfaat yang diberikan lebih besar dari biaya akibat hutang sendiri, dan perusahaan masih bisa menambah hutang apabila perusahaan tersebut masih memiliki aset yang gunakan untuk jaminan dalam peroleh hutang tersebut, tapi jika perusahaan telah banyak menggunakan hutang atau sudah terlalu tinggi, sebaik perusahaan tidak melakukan penambahan hutang untuk menghindari risiko yang tidak diingikan dikemudian hari. Trade off theory juga dapat sebagai bahan pertimbangan yang penting bagi perusahaan, jika perusahaan yang memiliki aset yang banyak, sebaiknya perusahaan menggunakan hutang lebih sedikit dan memaksimalkan menggunakan aset yang dimemiliki perusahaan untuk memenuhi dana yang dibutuhkan oleh perusahaan. Namun dalam trade off theory mengatakan perusahaan tidak bisa mencapai nilai optimal apabila pendanaan menggunakan hutang sepenuhnya atau tidak menggunakan hutang sama sekali.

\section{Struktur Modal}

Struktur modal adalah perimbangan atau perbandingan antara modal asing (jangka panjang) dengan modal sendiri (Riyanto, 2011). Pengukuran struktur modal memiliki berbagai macam rasio perhitungan, hal ini tergantung dengan tujuan yang ditetapkan. Bauran antara utang dengan ekuitas perusahaan merupakan hasil keputusan 
manajemen yaitu keputusan dalam pendanaan sebagai salah satu fungsi pokok manajemen keuangan. Bauran tersebut dapat diukur dengan rasio leverage. Variabel leverage dalam penelitian ini mengacu pada financial leverage, dimana financial leverage dapat diartikan sebagai besarnya beban tetap keuangan yang digunakan oleh perusahaan, dan beban tetap tersebut biasanya berasal dari pembayaran bunga untuk utang yang digunakan oleh perusahaan (Wiksuana dan Krisnanda 2015). Proporsi penggunaan utang jangka panjang (long term debt) terhadap total aset dianggap dapat menggambarkan kebijakan struktur modal yang dilakukan oleh perusahaan.

\section{Profitabilitas}

Profitabilitas merupakan kamampuan perusahaan untuk memperoleh laba dari kegiatan bisnis yang di lakukan. Perusahaan yang memiliki profitabilitas yang tinggi cenderung menggunakan hutang yang relatif kecil karena saldo laba yang tinggi sudah mencukupi untuk membiayai seberapa besar kebutuhan dana perusahaan. Menurut Brigham dan Houston (2011), perusahaan dengan tingkat pengembalian yang tinggi atas investasi menggunakan utang yang relatif kecil karena tingkat pengembalian yang tinggi memungkinkan perusahaan untuk membiayai sebagian besar pendanaan internal.

\section{Likuiditas}

Menurut Fahmi (2015) Likuiditas adalah seberapa besar kemampuan perusahaan dalam memenuhi kewajiban jangka pendeknya pada saat jatuh tempo. Likuiditas suatu perusahaan dapat diketahui dari neraca atau laporan keuangan yaitu dengan membandingkan jumlah aset lancar dengan utang lancar.

\section{Ukuran Perusahaan}

Ukuran perusahaan adalah salah satu yang digunakan oleh perusahaan untuk menentukan berapa besar kebijakan struktur modal dalam memenuhi besar aset suatu perusahaan (Ardiana dan Adiyana 2014). Dalam hal ukuran perusahaan dilihat dari total aset yang dimiliki oleh perusahaan, yang dapat dipergunakan untuk kegiatan operasi perusahaan. Jika perusahaan memiliki total aset yang besar, pihak manajemen lebih mudah dalam mempergunakan aset yang ada di perusahaan tersebut. Kebebasan yang dimiliki manajemen ini sebanding dengan kekhawatiran yang dilakukan oleh pemilik atas asetnya. Jumlah aset yang besar akan menurunkan nilai perusahaan jika dinilai dari sisi pemilik perusahaan.

\section{Pertumbuhan penjualan}

Pertumbuhan penjualan merupakan indikator maju atau tidaknya suatu perusahaan. Suatu perusahaan yang berada dalam industri yang memiliki laju pertumbuhan yang tinggi harus menyediakan modal yang cukup untuk membiayai kegiatan operasional perusahaan. Perusahaan yang pertumbuhannya pesat cenderung lebih banyak menggunakan hutang daripada perusahaan yang pertumbuhannya lambat. Penjualan memiliki pengaruh yang strategis bagi sebuah perusahaan karena penjualan yang dilakukan harus didukung dengan aset dan bila penjualan ditingkatkan maka aset pun harus ditambah.

\section{Dividend payout rasio}


Dividend Payout Ratio merupakan kebijakan dividen yang dilakukan perusahaan dalam menentukan berapa banyak jumlah laba yang akan dibagikan sebagai dividen kepada pemegan saham dan berapa banyak saldo laba yang akan digunakan sebagai sumber pendanaan.

\section{Perumusan Hipotesis}

\section{Pengaruh profitabilitas terhadap struktur modal}

Profitabilitas merupakan kamampuan perusahaan untuk memperoleh laba dari kegiatan bisnis yang di lakukan. Perusahaan yang memiliki profitabilitas yang tinggi cenderung menggunakan hutang yang relatif kecil karena saldo laba yang tinggi sudah mencukupi untuk membiayai seberapa besar kebutuhan dana perusahaan. Menurut Brigham dan Houston (2011) perusahaan dengan tingkat pengembalian yang tinggi atas investasi menggunakan utang yang relatif kecil karena tingkat pengembalian yang tinggi memungkinkan perusahaan untuk membiayai sebagian besar pendanaan internal perusahaan dengan tingkat pengembalian yang tinggi atas investasi menggunakan hutang yang relatif kecil. Tingkat pengembalian yang tinggi memungkinkan untuk membiayai sebagian besar kebutuhan pendanaan dengan dana yang dihasilkan secara internal. Semakin tinggi profitabilitas menunjukkan bahwa laba yang diperoleh perusahaan juga tinggi.

Jika laba perusahaan tinggi maka perusahaan memiliki sumber dana dari dalam yang cukup besar sehingga perusahaan lebih sedikit memerlukan hutang. Selain itu, saldo laba bertambah, rasio hutang dengan sendirinya akan menurun, dengan asumsi bahwa perusahaan tidak menambah jumlah hutang. Menurut Mustanda dan Angelina (2016) dalam penelitiannya menyatakan bahwa profitabilitas memiliki pengaruh negatif dan signifikan terhadap struktur modal.Widati dan Farisa (2017) menyatakan dalam penelitiannya bahwa profitabilitas tidak memilki pengaruh terhadap struktur modal. Sampurno dan Guna (2018) juga menyatakan dalam penelitianya bahwa profitabilitas memiliki pengaruh positif terhadap struktur modal. Hipotesis yang diajukan adalah:

\section{$H_{1}$ : Profitabilitas berpengaruh terhadap struktur modal}

\section{Pengaruh likuiditas terhadap struktur modal}

Perusahaan dengan likuiditas yang tinggi mempunyai dana internal yang besar, sehingga perusahaan tersebut akan lebih menggunakan dana internalnya terlebih dahulu untuk membiayai kegiatan operasionalnya sebelum menggunakan pembiayaan ekternal. Menurut pecking order theory, peruasahaan yang mempunyai likuiditas yang tinggi akan cenderung tidak menggunakan pembiayaan dari hutang (Ardiana dan Adiyana 2014). Menurut Ardiana dan Adiyana (2014) dalam penelitiannya menyatakan bahwa likuiditas positif dan signifikan terhadap struktur modal. Widati dan Farisa (2017) dalam penelitiannya menyatakan bahwa likuiditas memiliki pengaruh negatif dan signifikan terhadap struktur modal. Hipotesi yang diajukan adalah.

\section{$\mathrm{H}_{2}$ : Likuiditas berpengaruh terhadap struktur modal}

\section{Pengaruh ukuran perusahaan terhadap struktur modal}

Ukuran perusahaan merupakan suatu indikator yang menunjukkan kekuatan financial perusahaan. Perusahaan besar dapat mengakses pasar modal dan memiliki fleksibelitas dan kemampuan lebih untuk mendapatkan dana (Joni \& Lina, 2010). Semakin besar ukuran perusahaan menunjukkan bahwa perusahaan tersebut 
memiliki jumlah aset yang semakin tinggi pula. Perusahaan yang memiliki ukuran yang relatif besar pun akan cenderung menggunkan dana eksternal yang semakin besar. Hal ini disebabkan kebutuhan dana juga semakin meningkat seiring dengan pertumbuhan perusahaan. Selain pendanaan internal, alternatif selanjutnya adalah pendanaan eksternal. Menurut Wiksuana dan Krisnanda (2015) dalam penelitiannya menyatakan bahwa ukuran perusahaan memiliki pengaruh negatif dan tidak signifikan. Dewi dan Juliantika (2016) dalam penelitiannya menyatakan bahwa ukuran perusahaan berpengaruh positif terhadap struktur modal. Sedangkan dalam penelitian Sampurno dan Guna (2018) menyatakan bahwa ukuran perusahaan tidak berpengaruh terhadap struktur perusahaan. Maka hipotesis yang diajukan adalah.

$\boldsymbol{H}_{3}$ : Ukuran perusahaan berpengaruh terhadap struktur modal

\section{Pengaruh pertumbuhan penjualan terhadap struktur modal}

Suatu perusahaan yang penjualannya relatif stabil dapat secara aman mengambil utang dalam jumlah yang besar dan mengeluarkan beban tetap yang lebih tinggi dibandingkan dengan perusahaan yang penjualan tidak stabil (Brigham \& Houston, 2011). Selain itu perusahaan dengan tingkat pertumbuhan penjualan yang tinggi akan lebih mudah untuk memperoleh hutang. Mustanda dan Angelina (2016) dalam penelitiannya menyatakan pertumbuhan penjualan memiliki pengaruh positif terhadap terhadap struktur laba, sedangkan Sumpurno dan Guno (2018) menyatakan dalam penelitinya bahwa pertumbuhan penjual tidak memiliki pengaruh signifikan terhadap struktur modal. Maka hipotesis yang diajukan adalah.

\section{$H_{4}$ : Pertumbuhan penjualan berpangaruh terhadap stuktur modal}

Pengaruh dividend payout ratio terhadap struktur modal

Kebijakan dividen dapat menjadi signal bagi investor untuk menilai kinerja perusahaan, hal ini disebabkan karena kebijakan berdampak terhadap harga saham perusahaan (Mardiyati, dkk, 2012 dalam Sari 2014). Eviani (2015) dalam penelitiannya menyatakan bahwa dividend payout ratio berpengaruh signifikan terhadap struktur modal, sedangkan dalam penelitian Sari (2014) mengatakan dividend payout ratio tidak berpengaruh signifkan terhadap struktur modal. Hipotesis yang di ajukan:

$H_{5}$ : Dividend payout ratio berpengaruh terhadap struktur modal

\section{Metode Penelitian JENIS PENELITIAN}

Penelitian ini merupakan penelitian kuantitatif. Penelitian kuantitatif merupakan penelitian yang lebih menekankan pengujian teori melalui pengukuran variabel penelitian dengan angka serta data dianalisis dengan menggunakan prosedur statistik.

\section{POPULASI DAN SAMPEL PENELITIAN \\ Populasi Penelitian}

Populasi dalam penelitian ini adalah perusahaan property dan realestate yang terdafta selama 2013-2017 di Bursa Efek Indonesia. Jumlah perusahaan yang terdaftar di BEI selama tahun 2013-2017 adalah 38 perusahaan 


\section{Sampel Penelitian}

Pemilihan sampel dilakukan dengan menggunakan metode purposive sampling dengan tujuan untuk mendapatkan sampel yang representatif sesuai dengan kriteria yang ditentukan. Adapun kriteria dari sampel yang akan digunakan yaitu:

1. Perusahaan property dan realestate yang terdaftar di Bursa Efek Indonesia secara kontisten selama tahun 2013-2017.

2. Perusahaan property dan realestate yang menyajikan secara lengkap dan berturut-turut menerbitkan laporan keuangan dari tahun 2013-2017.

3. Perusahaan property dan realestate yang tidak mengungkapkan laba negatif atau mengalami kerugian dalam laporan keuangan selama tahun 2013-2017.

4. Perusahaan property dan realestate yang menerbitkan laporan keuangan dalam satuan mata uangan rupiah.

5. Memiliki data yang lengkap berkaitan dengan variabel yang akan digunakan dalam penelitian ini.

Berdasarkan teknik pengambilan sampel diatas, maka sampel yang digunakan dalam penelitian ini sebanyak 28 perusahaan property dan realestate yang telah memenuhi kriteria.

\section{OPERASIONALISASI VARIABEL}

Definisi operasional adalah uraian tentang batasan variabel atau tentang apa yang diukur oleh variabel yang bersangkutan. Definisi operasional variabel meliputi variabel dependen dan variabel independen.

\section{Variabel Dependen}

Variabel dependen dalam penelitian adalah struktur modal. Struktur modal (DER) adalah rasio yang mengukur perbandingan hutang dan ekuitas dalam pendanaan perusahaan dan menunjukkan kemampuan modal sendiri perusahaan untuk memenuhi seluruh kewajiban. Pengukuran struktur modal dalam penelitian ini diwakili debt to total equity ratio (DER). Menurut Fahmi (2015) rumus DER adalah sebagai berikut :

$$
\text { Debt to equity rasio }=\frac{\text { Total hutang }}{\text { Total ekuitas }}
$$

\section{Variabel Independen}

Variabel Independen merupakan variabel yang mempengaruhi atau menjadi sebab terjadinya perubahan terhadap variabel dependen.

\section{Profitabilitas}

Profitabilitas merupakan kemampuan perusahaan untuk memperoleh laba dari kegiatan yang dilakukan oleh perusahaan. Profitabilitas menggunakan ukuran Net Profit Margin (NPM), dihitung berdasarkan laporan keuangan perusahaan setiap tahun. Menurut Sujarweni (2012) rumus net profit margin adalah sebagai berikut: 


$$
\text { Net prof it margin }=\frac{\text { Laba setelah pajak }}{\text { Penjualan bersih }}
$$

\section{Likuiditas}

Rasio likuiditas merupakan rasio yang mengukur kemampuan perusahaan dalam jangka pendek dengan melihat aset lancar perusahaan terhadap hutang lancar. Rasio likuiditas dalam penelitian ini diwakili oleh current ratio. Menurut Fahmi (2015) rumus untuk mengukur current ratio dengan rumus sebagai berikut :

$$
\text { Current rasio }=\frac{\text { Aset lancar }}{\text { Liabilitas jangka pendek }}
$$

\section{Ukuran Perusahaan}

Ukuran perusahaan adalah salah satu faktor yang digunakan perusahaan untuk menentukan berapa besar kebijakan struktur modal dalam memenuhi besar aset suatu perusahaan (Adiana dan Adiyan 2014) . ukuran perusahan diukur dengan proksi berdasarkan total aset. Ukuran perusahaan dapat dirumuskan sebagai berikut:

$$
\text { Size }=\text { Ln Total Asset }
$$

\section{Pertumbuhan Penjualan}

Pertumbuhan penjualan adalah kenaikan atau penurunan jumlah penjualan dari tahun ke tahun atau dari waktu ke waktu. Menurut Wasana (2008) pengukuran pertumbuhan penjualan dapat dihitung dengan dirumus sebagai berikut:

$$
\text { Pertumbuhan penjualan }=\frac{\text { Penjualan }(\mathrm{t})-\text { penjualan }(\mathrm{t}-1)}{\text { Penjualan }(\mathrm{t}-1)}
$$

\section{Dividend Payout Ratio}

Dividend Payout Ratio (DPR) merupakan kebijakan dividen yang dilakukan perusahaan dalam menentukan berapa banyak jumlah laba yang akan dibagikan kepada sebagai dividen kepada pemegang saham dan berapa banyak saldo laba yang akan digunakan sebagai sumber pendanaan. Rasio ini digunakan untuk melihat seberapa besar jumlah dividen yang dibagikan kepada pemilik saham dibandingkan dengan jumlah laba yang dihasilkan oleh perusahaan. Menurut mahmud (2009) pengukuran dividend payout ratio dapat mengunakan rumus sebagai berikut:

$$
\text { Dividend payout ratio }=\frac{\text { Dividend per lembar }}{\text { Earning per lembar }}
$$

\section{Tenik Analisis Data}


Penelitian ini menggunakan model regresi berganda dengan bantuan IBM SPSS Statistics 20. Analisis regresi ini bertujuan untuk memperoleh gambaran yang menyeluruh mengenai hubungan antara variabel independen dan variabel dependen.

\section{Statistik Deskriptif}

Statistik deskriptif adalah statistik yang digunakan untuk menganalisa data dengan cara mendeskripsikan atau menggambarkan data yang telah terkumpul sebagaimana adanya tanpa bermaksud membuat kesimpulan yang berlaku untuk umum atau generalisasi. Statistik deskriptif digunakan untuk menggambarkan variabel-variabel dalam penelitian ini. Analisis ini akan menghasilkan rata-rata (mean), nilai maksimal (maximum), nilai minimal (minimum), dan standar deviasi untuk mendeskripsikan variabel penelitian. Sehingga penelitian ini mudah dipahami secara kontekstual oleh pembaca.

\section{Uji Asumsi Klasik}

Sebelum melakukan uji regresi linear berganda, perlu dilakukan uji asumsi klasik terlebih dahulu agar mendapatkan hasil yang terbaik. Tujuannya adalah dimaksudkan agar variabel bebas sebagai estimator atas variabel terikat tidak bias.

\section{Uji Normalitas}

Uji Normalitas bertujuan untuk menguji apakah dalam model regresi, variabel pengganggu atau residual memiliki distribusi normal. Seperti diketahui bahwa uji $\mathrm{t}$ dan $\mathrm{F}$ mengasumsikan bahwa nilai residual mengikuti distribusi normal. Kalau asumsi ini dilanggar maka uji statistik menjadi tidak valid untuk jumlah sampel yang kecil (Ghozali,2013). Menurut Ghozali (2013) Suatu model dikatakan memenuhi asumsi normalitas apabila data menyebar disekitar garis diagonal dan mengikuti arah garis diagonal atau grafik histogramnya menunjukkan pola distribusi normal. Cara lain untuk mendeteksi normalitas adalah dengan uji Statistic Kolmogorov-Smirnov. Uji Kolmogorov-Smirnov dua arah ini menggunakan derajat kepercayaan 5\%. Distribusi variabel-variabel bebas dan terikat adalah normal jika:

Signifikansi $>0,05$ maka data berdistribusi normal

Signifikansi $<0,05$ maka data tidak berdistribusi normal

\section{Uji Multikolonieritas}

Uji multikolonieritas bertujuan untuk menguji apakah model regresi ditemukan adanya korelasi antar variabel bebas (independen). Model regresi yang baik seharusnya tidak terjadi korelasi di antara variabel independen. Jika variabel independen saling berkolerasi, maka variabel-variabel ini tidak ortogonal. Variabel ortogonal adalah variabel independen yang nilai korelasi antar sesama variabel independen sama dengan nol (Ghozali, 2013).

Cara untuk mendeteksi ada atau tidaknya multikolonieritas dapat dilihat dari nilai Tolerance dan lawannya serta Variance Inflation Factor (VIF). Kedua ukuran ini menunjukkan setiap variabel independen manakah yang dijelaskan oleh variabel independen lainnya. Dalam pengertian sederhana setiap variabel independen mejadi variabel dependen (terikat) dan diregres terhadap variabel independen lainnya. Tolerance mengukur variabilitas variabel independen yang terpilih yang tidak dijelaskan oleh variael independen lainnya. Variabel dikatakan lulus uji multikolonieritas apabila nilai tolerance kurang dari 0,10 yang berarti tidak ada korelasi diantara variabel independen dan nilai VIF tidak lebih dari 10 (Ghozali, 2013). 


\section{Uji Autokorelasi}

Uji Autokorelasi bertujuan menguji apakah dalam suatu model regresi linear ada korelasi antara kesalahan pengganggu pada periode $t$ dengan kesalahan pada periode t-1 (sebelumnya). Jika terjadi korelasi maka dinamakan ada problem autokorelasi. Model regresi yang baik adalah regresi yang bebas dari autokorelasi. Uji autokorelasi dapat dilakukan dengan menggunakan uji Durbin-Watson (D-W) dengan dasar pengambilan keputusan apabila $\mathrm{du}<\mathrm{dw}<4$-du maka dikatakan tidak terjadi autokorelasi. Cara lain dengan uji Run Test yaitu jika asymp sig (2-tailed) pada output runs test lebih besar dari 0,05, maka data tidak mengalami atau mengandung autokorelasi dan sebaliknya (Ghozali, 2013).

\section{Uji Heteroskedastisitas}

Uji heteroskedastisitas adalah untuk menguji apakah dalam model regresi terjadi ketidaksamaan varians dari residual dari suatu pengamatan ke pengamatan yang lain. Jika varians dari residual dari suatu pengamatan ke pengamatan lain tetap maka disebut homokedastisitas. Jika varian berbeda, disebut heteroskedastisitas. Model regresi yang baik adalah tidak terjadi heteroskedastisitas (Ghozali 2013).

Untuk mendeteksi ada tidaknya heteroskedastisitas dalam model regresi bisa dilihat dengan cara melihat Grafik Plot antara nilai prediksi variabel terikat yaitu ZPRED dengan residualnya SRESID. Deteksi ada tidaknya heteroskedastisitas dapat dilakukan dengan melihat ada tidaknya pola tertentu pada grafik scatterplot antara SRESID dan ZPRED. Jika tidak ada pola yang jelas, serta titik-titik menyebar di atas dan di bawah angka 0 pada sumbu Y maka tidak terjadi Heteroskedastisitas (Ghozali, 2013).

\section{Analisis Regresi Linear Berganda}

Tujuan analisis regresi berganda adalah untuk memperkirakan perubahan respon pada variabel terikat terhadap beberapa variabel bebas. Model persamaan regresi yang akan diuji dalam penelitian ini adalah sebagai berikut:

\begin{tabular}{ll}
\hline DER $=\mathrm{a}+b_{1} \mathrm{NPM}+b_{2} \mathrm{CR}+b_{3} \mathrm{SIZE}+b_{4} \mathrm{PP}+b_{5} \mathrm{DPR}+\mathrm{e}$ \\
\hline Keterangan: & $=$ Struktur modal \\
DER & $=$ Konstanta \\
$\mathrm{a}$ & $=$ Koefisien regresi variabel independen \\
$b_{1}, b_{2}, b_{3}, b_{4}, b_{5}$ & $=$ Profitabilitas \\
NPM & $=$ Likuiditas \\
CR & $=$ Ukuran Perusahaan \\
SIZE & $=$ Pertumbuhan Penjualan \\
PP & $=$ Dividen Payout Rasio \\
DPR &
\end{tabular}


$\mathrm{e}$

$$
=\text { Error } / \text { residu }
$$

\section{Uji Hipotesis}

\section{Koefisien Determinasi (R2)}

Koefisien determinasi $\left(\mathrm{R}^{2}\right)$ pada intinya mengukur seberapa jauh kemampuan model dalam menerapkan variasi variabel dependen. Nilai koefisien determinasi adalah nol atau satu. Nilai $\mathrm{R}^{2}$ yang kecil berarti kemampuan variabel- variabel independen dalam mejelaskan variasi variabel dependen amat terbatas. Nilai koefisien determinasi ditunjukkan dengan nilai adjusted $R$ Square bukan R Square dari model regresi karena R Square bias terhadap jumlah variabel dependen yang dimasukkan ke dalam model, sedangkan adjusted $R$ Square dapat naik turun jika suatu variabel independen ditambahkan dalam model (Ghozali, 2013).

\section{Uji Signifikansi Simultan (Uji Statistik F)}

Pengujian secara simultan uji $F$ (pengujian signifikansi secara simultan). Uji $F$ dilakukan untuk menguji apakah secara serentak variabel independen mampu menjelaskan variabel dependen secara baik atau untuk menguji apakah model yang digunakan telah sig atau tidak. Jika nilai signifikansi $\mathrm{F}<0,025$ maka secara bersamasama variabel independen memiliki pengaruh yang signifikan terhadap variabel dependen.

\section{Uji (Uji t)}

Uji t adalah pengujian yang dilakukan untuk mengetahui hubungan variabel bebas terhadap variabel terkait secara persial. Uji hipotesis t dilakukan untuk mengetahui seberapa jauh pegaruh antara variabel independen secara individu terhadap variabel dependen. Penelitian ini bertujuan untuk menguji pengaruh profitabilitas, likuiditas, ukuran perusahaan, pertumbuhan penjualan dan dividend payout ratio terhadap struktur modal. Jika nilai signifikansi lebih kecil dari 0,025 maka terdapat pengaruh yang kuat antara kedua variabel.

\section{Hasil Penelitian \\ Statistik Deskriptif}

Tabel 1

Statistik Deskriptif

Descriptive Statistics

\begin{tabular}{|l|r|r|r|r|r|}
\hline & \multicolumn{1}{|c|}{ N } & \multicolumn{1}{c|}{ Minimum } & Maximum & \multicolumn{1}{c|}{ Mean } & \multicolumn{1}{c|}{ Std. Deviation } \\
\hline DER & 137 &, 08 & 1,93 &, 8218 &, 43849 \\
NPM & 137 &, 01 & 15,09 &, 4191 & 1,29622 \\
CR & 137 &, 12 & 8,80 & 2,2707 & 1,57091 \\
SIZE & 137 & 21,77 & 31,67 & 28,3385 & 2,47434 \\
PP & 137 &,- 87 & 2,99 &, 1608 &, 49103 \\
DPR & 137 &, 00 & 4,58 &, 2094 &, 62778 \\
Valid N (listwise) & 137 & & & & \\
\hline
\end{tabular}

Sumber: Output IBM SPSS Versi 20.0

Berdasarkan hasil uji statistik deskriptif pada tabel 1 diketahui bahwa jumlah data dalam penelitian (N) adalah 137 data dan dapat diketahui bahwa:

1. Variabel struktur modal memiliki nilai rata-rata sebesar 0,8218 , hal ini menunjukkan bahwa sebagian besar perusahaan yang menjadi sampel 
mempunyai nilai struktur modal yang positif dengan standar deviasi 0,43849 dari sampel 137 sampel, variabel struktur modal memiliki nilai minimum 0,08 dan nilai maksimum 1,93 .

2. Variabel profitabilitas memiliki nilai rata-rata sebesar 0,4191 hal ini menunjukkan bahwa sebagian besar perusahaan yang menjadi sampel mempunyai nilai profitabilitas yang positif dengan standar deviasi 1,29622 dari 137 sampel dan variabel profitabilitas memiliki nilai minimum 0,01 dan nilai maksimum 15,09.

3. Likuiditas memiliki nilai rata-rata sebesar 2,2707 hal ini menunjukkan bahwa sebagian besar perusahaan yang menjadi sampel mempunyai nilai likuiditas yang positif dengan standar deviasi 1,57091 dari 137 sampel dan variabel likuiditas memiliki nilai minimum 0,12 dan nilai maksimum 8,80.

4. Selain itu ukuran perusahaan juga memiliki nilai rata-rata sebesar 28,3385 hal ini menunjukkan bahwa sebagian besar perusahaan yang menjadi sampel mempunyai nilai ukuran perusahaan yang positif dengan standar deviasi 2,47434 dari 137 sampel dan variabel ukuran perusahaan memiliki nilai minimum 21,77 dan nilai maksimum 31,67.

5. Variabel pertumbuhan penjualan juga memiliki nilai rata-rata sebesar 0,1608 hal ini menunjukkan bahwa sebagian besar perusahaan yang menjadi sampel mempunyai nilai pertumbuhan penjualan yang positif dengan standar deviasi 0,49103 dari 137 sampel dan variabel pertumbuhan penjualan memiliki nilai minimum -0,87 dan nilai maksimum 2,99.

6. Selanjutnya dividend payout ratio memiliki nilai rata-rata sebesar 0,2094 hal ini menunjukkan bahwa sebagian besar perusahaan yang menjadi sampel mempunyai nilai dividen payout ratio yang positif dengan standar deviasi 0,62778 dari 137 sampel dan variabel dividend payout ratio memiliki nilai minimum 0,00 dan nilai maksimum 4,58.

\section{Uji Asumsi Klasik}

Uji Normalitas

Hasil uji normalitas dapat dilihat dari tabel dibawah ini.

Tabel 2

Hasil Uji Kolmogorov Smirnov Test

One-Sample Kolmogorov-Smirnov Test

\begin{tabular}{|ll|l|}
\hline & & $\begin{array}{l}\text { Unstandardized } \\
\text { Residual }\end{array}$ \\
\hline N & & 137 \\
Normal Parameters & & $0 \mathrm{E}-7$ \\
& Mean &, 39783848 \\
& Std. Deviation &, 079 \\
Most Extreme Differences & Absolute &, 079 \\
& Positive &,- 061 \\
Kolmogorov-Smirnov Z & Negative &, 930 \\
Asymp. Sig. (2-tailed) & &, 353 \\
\hline
\end{tabular}

a. Test distribution is Normal.

b. Calculated from data.

Sumber: Output IBM SPSS Versi 20.0 
Hasil uji Kolmogorov Smirnov yang terdapat pada Tabel 2 menunjukkan bahwa nilai probabilitas 0,353 lebih besar dari tingkat signifikansi 0,05 sehingga dapat disimpulkan bahwa data penelitian terdistribusi normal.

\section{Uji Multikolonieritas}

Pengujian multikolinearitas ini dilakukan untuk mengetahui apakah variabel bebas tersebut saling berkolerasi. Model regresi yang baik seharusnya tidak terjadi korelasi diantara variable independen. Uji multikolinearitas dilakukan dengan cara melihat nilai variance inflation factor (VIF).Jika nilai VIF $\geq 10$, maka dapat dikatakan terdapat gejala multikolinearitas dan jika nilai VIF < 10 maka tidak ada gejala multikolinearitas. Berikut tabel hasil pengolahan data untuk uji multikolinieritas.

Tabel 3

Hasil Uji Multikolinieritas

Coefficients ${ }^{\mathrm{a}}$

\begin{tabular}{|c|c|c|c|c|c|c|c|c|}
\hline \multirow{2}{*}{\multicolumn{2}{|c|}{ Model }} & \multicolumn{2}{|c|}{$\begin{array}{l}\text { Unstandardized } \\
\text { Coefficients } \\
\end{array}$} & \multirow{2}{*}{$\begin{array}{c}\begin{array}{c}\text { Standardized } \\
\text { Coefficients }\end{array} \\
\text { Beta }\end{array}$} & \multirow[t]{2}{*}{$\mathrm{T}$} & \multirow[t]{2}{*}{ Sig. } & \multicolumn{2}{|c|}{$\begin{array}{l}\text { Collinearity } \\
\text { Statistics }\end{array}$} \\
\hline & & $B$ & Std. Error & & & & $\begin{array}{c}\text { Toleranc } \\
\mathrm{e}\end{array}$ & VIF \\
\hline \multirow{6}{*}{1} & (Constant) & 1,811 & 403 & & 4,497 & , 000 & & \\
\hline & NPM &,- 045 & ,027 & - 132 & $-1,636$ & 104 & ,967 & 1,034 \\
\hline & CR &,- 088 & 023 &,- 314 & $-3,773$ & , 000 & 909 & 1,100 \\
\hline & SIZE &,- 028 & 014 & -160 & $-1,972$ & 051 & 949 & 1,054 \\
\hline & PP & 079 & ,072 & ,089 & 1,109 & 269 & ,976 & 1,025 \\
\hline & DPR & 104 & , 058 & 148 & 1,800 & ,074 & ,925 & 1,081 \\
\hline
\end{tabular}

a. Dependent Variable: DER

Sumber: Output IBM SPSS Versi 20.0

Berdasarkan hasil uji multikolinieritas pada Tabel 3 diatas, dapat dilihat bahwa semua variabel independen menunjukkan nilai tolerance lebih besar dari 0,1 dan nilai VIF tidak lebih dari 10. Dengan ini dapat disimpulkan tidak terjadi multikolinieritas antar variabel independen dalam model regresi.

\section{Uji Autokorelasi}

Uji autokorelasi bertujuan untuk menguji apakah dalam model regresi linear ada korelasi antara kesalahan pengganggu pada periode $t$ dengan kesalahan pengganggu pada periode t-1 sebelumnya. Cara mendeteksi autolorelasi dengan menggunakan uji Durbin-Watson. Jika du $<\mathrm{dw}<4$-du maka dapat dikatakan data terbebas dari autokorelasi. Hasil uji autokorelasi dapat dilihat pada tabel dibawah ini:

Tabel 4

Hasil Uji Autokorelasi

Model Summaryb

\begin{tabular}{|l|r|r|r|r|r|}
\hline Model & $R$ & $R$ Square & $\begin{array}{c}\text { Adjusted R } \\
\text { Square }\end{array}$ & $\begin{array}{c}\text { Std. Error of the } \\
\text { Estimate }\end{array}$ & Durbin-Watson \\
\hline 1 &, $421^{a}$ &, 177 &, 145 &, 40536 & 1,795 \\
\hline
\end{tabular}
a. Predictors: (Constant), DPR, NPM, SIZE, PP, CR
b. Dependent Variable: DER
Sumber: Output IBM SPSS Versi 20.0




\section{Uji Heteroskedastisitas}

Uji ini dilakukan untuk menguji apakah dalam model regresi tersebut terjadi ketidaksamaan varians dari residual suatu pengamatan ke pengamatan yang lain. Model regresi dalam kondisi baik jika tidak mengalami heterokedastisitas. Pada uji heteroskedastisitas ini penulis mendeteksi ada atau tidaknya heteroskedastisitas dengan melihat grafik plot. Jika tidak ada pola yang jelas, serta titik-titik menyebar di atas dan di bawah angka 0 pada sumbu Y, maka tidak terjadi heteroskedastisitas (Ghozali, 2013). Berdasarkan pengujian dengan menggunakan SPSS diperoleh grafik Scatterplot sebagai berikut:

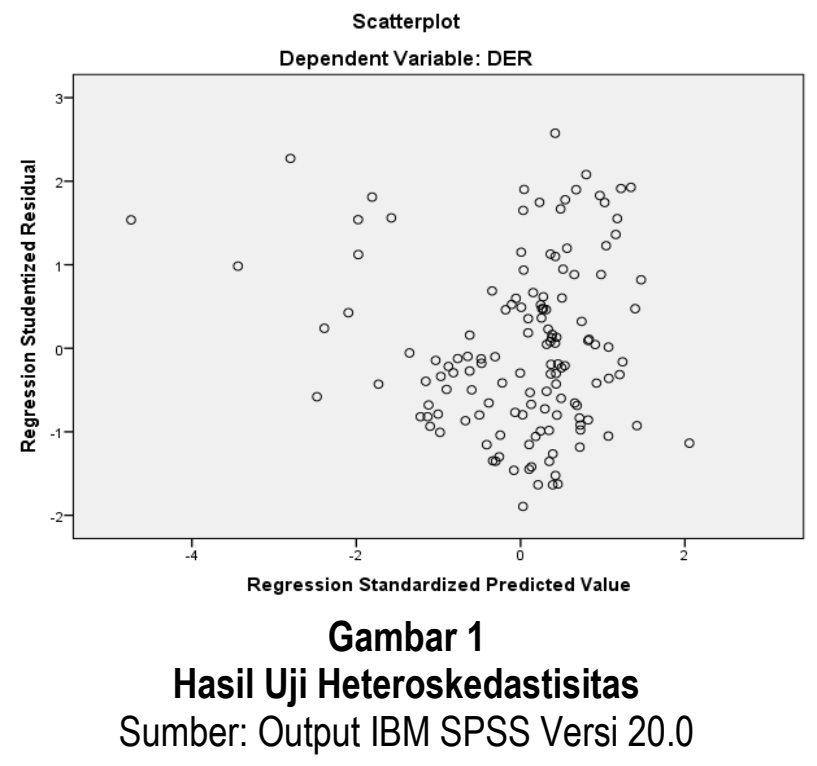

Dari gambar tersebut terlihat bahwa titik-titik tersebut menyebar secara acak dan tidak membentuk suatu pola tertentu, sehingga dapat dikatakan tidak terjadi gejala heterokedastisita, sehingga layak dipakai untuk memprediksi struktur modal (DER) berdasarkan masukan variabel independen profitabilitas (NPM), likuiditas (CR), ukuran perusahaan (SIZE), pertumbuhan penjualan (PP), dan dividend payout ratio (DPR). Berikut ini hasil uji Glejser dari uji heteroskedastisitas yang digunakan dalam penelitian ini

Tabel 4

Uji Glejser

Coefficients $^{\mathrm{a}}$

\begin{tabular}{|c|c|c|c|c|c|c|}
\hline \multirow[t]{2}{*}{ Mod } & & \multicolumn{2}{|c|}{ Unstandardized Coefficients } & \multirow{2}{*}{$\begin{array}{c}\text { Standardized } \\
\text { Coefficients } \\
\text { Beta } \\
\end{array}$} & \multirow[t]{2}{*}{$\mathrm{T}$} & \multirow[t]{2}{*}{ Sig. } \\
\hline & & B & Std. Error & & & \\
\hline \multirow{6}{*}{1} & (Constant) & ,549 & 228 & & 2,409 & ,017 \\
\hline & NPM &,- 016 & ,015 &,- 088 & $-1,013$ & ,313 \\
\hline & $C R$ &,- 003 & ,013 &,- 024 &,- 266 & ,791 \\
\hline & SIZE &,- 007 & ,008 &,- 076 &,- 868 & ,387 \\
\hline & PP & , 000 & ,041 & 000 & ,005 & ,996 \\
\hline & DPR &,- 050 & ,033 &,- 136 & $-1,523$ & 130 \\
\hline
\end{tabular}


Dari tabel 4.6 dapat disimpulkan bahwa tidak terjadi heteroskedastisitas dalam uji heteroskedastisitas, hal ini disebabkan karena nilai Sig. yang diperoleh dalam uji heteroskedastisitas $>0,025$.

\section{Hasil Pengujian Regresi}

\section{Koefisien Determinasi (R2)}

Koefisien determinasi pada intinya mengukur seberapa jauh kemampuan model dalam menerapkan variasi variabel dependen. Nilai koefisien determinasi adalah nol atau satu. Nilai yang kecil berarti kemampuan variabel- variabel independen dalam mejelaskan variasi variabel dependen amat terbatas. Hasil uji determinasi dapat dilihat di bawah ini:

Tabel 5

Hasil Uji Determinasi

Model Summary

\begin{tabular}{|l|r|r|r|r|}
\hline Model & $\mathrm{R}$ & $\mathrm{R}$ Square & \multicolumn{1}{|c|}{$\begin{array}{c}\text { Adjusted } \mathrm{R} \\
\text { Square }\end{array}$} & $\begin{array}{c}\text { Std. Error of the } \\
\text { Estimate }\end{array}$ \\
\hline 1 &, $421 \mathrm{a}$ &, 177 &, 145 &, 40536 \\
\hline
\end{tabular}

a. Predictors: (Constant), DPR, NPM, SIZE, PP, CR

Berdasarkan tabel 5 diatas dapat lihat untuk nilai Adjusted R Square adalah sebesar 0,145. Hal ini berarti profitabilitas, likuiditas, ukuran perusahaan, pertumbuhan penjualan, dividend payout ratio berpengaruh $14,5 \%$ terhadap struktur modal dan sisanya $85,5 \%$ dipengaruhi oleh variabel-variabel lain diluar model penelitian.

\section{Uji Signifikansi Simultan (Uji F)}

Uji F dilakukan untuk menguji apakah secara serentak variabel independen mampu menjelaskan variabel dependen secara baik atau untuk menguji apakah model yang digunakan telah sig atau tidak. Jika nilai signifikansi $\mathrm{F}<0,025$ maka secara bersamasama variabel independen memiliki pengaruh yang signifikan terhadap variabel dependen.

Tabel 6

Hasil Uji F

ANOVA $^{\mathrm{a}}$

\begin{tabular}{|rl|r|r|r|r|r|}
\hline \multicolumn{1}{|l|}{ Model } & \multicolumn{1}{|c|}{$\begin{array}{c}\text { Sum of } \\
\text { Squares }\end{array}$} & Df & Mean Square & F & \multicolumn{1}{l|}{ Sig. } \\
\hline \multirow{2}{*}{1} & Regression & 4,624 & 5 &, 925 & 5,628 &, $000^{\mathrm{b}}$ \\
& Residual & 21,525 & 131 &, 164 & & \\
& Total & 26,149 & 136 & & & \\
\hline
\end{tabular}

a. Dependent Variable: DER

b. Predictors: (Constant), DPR, NPM, SIZE, PP, CR

Sumber: Output IBM SPSS Versi 20.0

Berdasarkan tabel 6 hasil uji $\mathrm{F}$ atau anova didapat nilai $\mathrm{F}$ hitung sebesar 5,628 dengan probabilitas (signifikan) 0,000. Karena signifikan jauh lebih kecil dari 0,025, maka menunjukkan bahwa secara bersama-sama atau simultan variabel independen 
profitabilitas, likuiditas, ukuran perusahaan, pertumbuhan penjualan, dividend payout ratio berpengaruh terhadap struktur modal.

\section{Uji t (Uji Parsial)}

Uji t adalah pengujian yang dilakukan untuk mengetahui hubungan variabel bebas terhadap variabel terkait secara persial. Uji hipotesis t dilakukan untuk mengetahui seberapa jauh pegaruh antara variabel independen secara individu terhadap variabel dependen. Jika nilai signifikansi lebih kecil dari 0,025 maka terdapat pengaruh yang kuat antara kedua variabel.

Tabel 7

Hasil Uji t

Coefficientsa

\begin{tabular}{|c|c|c|c|c|c|c|}
\hline \multirow[t]{2}{*}{ Moc } & & \multicolumn{2}{|c|}{ Unstandardized Coefficients } & \multirow{2}{*}{$\begin{array}{c}\text { Standardized } \\
\text { Coefficients } \\
\text { Beta }\end{array}$} & \multirow[t]{2}{*}{$t$} & \multirow[t]{2}{*}{ Sig. } \\
\hline & & $B$ & Std. Error & & & \\
\hline \multirow{6}{*}{1} & (Constant) & 1,811 & ,403 & & 4,497 & 000 \\
\hline & NPM &,- 045 & 027 &,- 132 & $-1,636$ & 104 \\
\hline & CR &,- 088 & 023 &,- 314 & $-3,773$ &, 000 \\
\hline & SIZE &,- 028 & 014 &,- 160 & $-1,972$ & ,051 \\
\hline & PP &, 079 & 072 & ,089 & 1,109 & ,269 \\
\hline & DPR & 104 & ,058 & , 148 & 1,800 & 074 \\
\hline
\end{tabular}

a. Dependent Variable: DER

Sumber: Output IBM SPSS Versi 20.0

Berdasarkan hasil uji t pada Tabel 7 diatas, profitabilitas (NPM) memiliki thitung -1,636 dengan signifikansi 0,104 lebih besar dari tingkat signifikansi 0,025 yang menunjukkan bahwa profitabilitas tidak memiliki berpengaruh terhadap struktur modal. Variabel likuiditas (CR) memiliki t-hitung -3,773 dengan signifikansi 0,000 lebih kecil dari tingkat signifikansi 0,025 yang menunjukkan bahwa likuiditas berpengaruh terhadap struktur modal. Ukuran perusahaan (SIZE) memiliki t-hitung 1,972 dengan signifikansi 0,051 lebih besar dari tingkat signifikansi 0,025 yang menunjukkan bahwa ukuran perusahaan tidak memiliki pengaruh terhadap struktur modal. Pertumbuhan penjualan (pp) memiliki t-hitung 1,109 dengan signifkansi 0,269 lebih besar dari tingkat signifikansi 0,025 yang menunjukkan bahwa pertumbuhan penjualan independen tidak berpengaruh terhadap struktur modal. Dividend payout ratio (dpr) memiliki t-hitung 1,800 dengan signifkansi 0,074 lebih besar dari tingkat signifikansi 0,025 yang menunjukkan bahwa dividend payout ratio tidak memiliki pengaruh terhadap struktur modal.

\section{PEMBAHASAN HASIL UJI HIPOTESIS}

\section{Pengaruh Profitabilitas terhadap Struktur Modal}

Berdasarkan hasil uji t pada Tabel 7 diatas, profitabilitas (NPM) memiliki nilai signifikansi 0,104 lebih besar dari tingkat signifikansi 0,025. Sehingga hipotesis 1 yang menyatakan profitabilitas berpengaruh terhadap struktur modal, "ditolak".

Hal ini bertolak belakang dengan pecking order theory yang mengatakan bahwa dengan meningkatnya profitabilitas perusahaan akan cendurung untuk menggunakan modal internal terlebih dahulu. Jika dilihat dari tabel statistik deskriptif rata-rata profitabilitas yang dimiliki perusahaan secara keseluruhan adalah sebesar 0,4206. Ini menandakan rata-rata profitabilitas perusahaan yang 
menjadi sampel cukup tinggi. Sebagai contoh dapat dilihat pada PT. Ciputra Development Tbk. Dimana Ciputra Development Tbk memiliki laba yang tinggi dan juga memiliki hutang yang tinggi. Hasil penelitian ini sama dengan hasil penelitian yang dilakukan Wadati dan Farisa (2017) yang menunjukan bahwa profitabilitas tidak berpangaruh signifikan terhadap struktur modal. Namun hal ini tidak sejalan dengan penelitian Dewi dan Juliantika (2016) yang menyatakan bahwa profitabilitas berpengaruh terhadap struktur modal. Hal ini sebabkan karena profitabilitas diproksikan dengan return on asset (ROA) dan tahun penelitiannya 2010-2014.

\section{Pengaruh Likuiditas terhadap Struktur Modal}

Berdasarkan hasil uji t pada tabel 7 likuiditas (CR) memiliki nilai signifikansi 0,000 lebih kecil dari tingkat signifikansi 0,025. Sehingga hipotesis 2 yang menyatakan likuiditas berpengaruh terhadap struktur modal, "dapat diterima".

Likuiditas menunjukkan kemampuan perusahaan dalam memenuhi kewajiban jangka pendeknya yang segera jatuh tempo. Dengan kata lain, rasio likuiditas adalah rasio yang mengukur seberapa jauh tingkat kemampuan perusahaan dalam memenuhi kewajiban jangka pendeknya yang akan segera jatuh tempo. Penelitian ini menggunakan current ratio. Rasio ini diukur dengan membandingkan antara total aset lancar dengan liabilitas jangka pendek.

Dilihat dari tabel statistik deskriptif rata-rata likuiditas yang dimiliki perusahaan secara keseluruhan adalah sebesar 2,2608. Dengan likuiditas yang tinggi perusahaan mempunyai aset yang cukup banyak yang untuk menjamin semua hutang. Ini menandakan rata-rata secara keseluruhan likuiditas cukup tinggi, hal ini dapat digambarkan dengan kondisi PT. Bumi Serpong Permai TBk, dimana perusahaan memiliki aset lancar besar dari pada liabilitas jangka pendek. Oleh karena itu, jika perusahaan memiliki aset lancar yang besar akan lebih mudah memperoleh hutang. Semakin tinggi kemampuan perusahaan dalam mengembalikan kewajiban-kewajiban jangka pendeknya maka semakin likuid perusahaan tersebut sehingga kepercayaan dari kreditur meningkat dan mempermudah perusahaan memperoleh hutang jangka panjangnya. Penelitian ini diperkuat oleh penelitian yang dilakukan oleh Sampurno dan Guna (2018) yang menyatakan bahwa likuiditas berpengaruh terhadap struktur modal. Namun tidak sejalan dengan penelitian Ardiana dan Adiyana (2014) yang menyatakan bahwa likuiditas tidak berpangaruh terhadap struktur modal. Hal ini karenakan perusahaann yang digunakan menjadi sampel berbeda yaitu manufaktur dan juga tahun gunakan 2008-2012.

\section{Pengaruh Ukuran perusahaan terhadap struktur modal}

Dari hasil uji t pada tabel 7 ukuran perusahaan (SIZE) memiliki nilai signifikansi 0,51 lebih besar dari tingkat signifikansi 0,025 . Sehingga hipotesis 3 yang menyatakan ukuran perusahaan berpengaruh terhadap struktur modal, "ditolak".

Penentuan besar kecilnya ukuran perusahaan dapat ditentukan berdasarkan total penjualan, total aset, rata-rata penjualan dan rata-rata total aset. Ukuran perusahaan pada penelitian ini diproksikan logaritma natural dari total aset. Perusahaan yang memiliki ukuran perusahaan yang besar, tidak menentukan perusahaan tersebut memiliki struktur modal yang bagus untuk kedepannya. Perusahaan yang besar terlihat dari total aset yang dimilikinya, namun jika aset diperoleh dari hutang tentu saja ini tidak baik bagi sebuah perusahaan walaupun perusahaan memiliki aset yang besar. Hal inilah yang menyebabkan investor tidak 
menjadikan ukuran perusahaan sebagai faktor yang menentukan keputusan berinvestasi.

Sebagai contoh PT. Bekasi Asri Permula Tbk yang memiliki ukuran perusahaan yang kecil, tetapi juga memiliki struktur modal besar diantara salah satu perusahaan yang termasuk dalam property dan realestate. Hasil Penelitian ini diperkuat dengan penelitian yang dilakukan oleh Sampurno dan Guna (2018) yang menyatakan bahwa ukuran perusahaan tidak memiliki pengaruh terhadap struktur modal. Namun hal ini tidak sejalan dengan penelitian ini Dewi dan Juliantika (2016) yang menyatakan bahwa likuiditas tidak berpangaruh terhadap struktur modal. Hal ini disebabkan karena tahun penelitian yang digunakan berbeda yaitu tahun 2010-2014.

\section{Pengaruh Pertumbuhan Penjualan terhadap Struktur Modal}

Dari hasil uji t pada tabel 7 pertumbuhan penjualan (PP) memiliki nilai signifkansi 0,269 lebih besar dari tingkat signifikansi 0,025. Sehingga hipotesis 4 yang menyatakan pertumbuhan penjualan berpengaruh terhadap struktur modal, "ditolak".

Bila dilihat dari tabel statistik deskriptif rata-rata pertumbuhan penjualan yang dimiliki perusahaan secara keseluruhan adalah sebesar 0,1655. Ini menandakan ratarata pertumbuhan penjualan yang menjadi sampel kecil, sebagai contoh dapat dilihat pada PT. Gading Development Tbk . Dimana PT. Gading Development Tbk yang memiliki pertumbahan penjualan tidak stabil atau mengalami penurunan setiap tahunnya dan juga memiliki struktur modal yang kecil. Hasil penelitian ini diperkuat oleh hasil penelitian yang dilakakan oleh Sampurno dan Guna (2018) yang manyatakan bahwa pertumbuhan penjualan tidak berpengaruh terhadap struktur modal. Namun penelitian ini tidak sejalan dengan penelitian Widati dan Farisa (2018) yang menyatakan bahwa pertumbuhan penjualan berpangaruh terhadap struktur modal. Hal disebakan karena perusahaan yang digunakan menjadi sampel yaitu manufaktur dan tahun penelitian yang gunakan juga berbeda 2012-2014.

\section{Pengaruh Dividend Payout Ratio terhadap Struktur Modal}

Dari hasil uji t tabel 7 Dividend payout ratio (DPR) memiliki nilai signifkansi 0,74 lebih besar dari tingkat signifikansi 0,025 . Sehingga hipotesis 5 yang menyatakan dividend payout ratio berpengaruh terhadap struktur modal, "ditolak".

Hasil hipotesis diatas didukung dengan kondisi perusahaan yang jadikan sampel, dimana perusahaan tersebut tidak melakukan pembayaran dividen setiap tahun dan juga ada perusahaan selama lima tahun berturut-turut tidak membagikan dividen. Hal ini dikarenakan perusahaan yang menjadi sampel memiliki keadaan penjualan yang tidak stabil setiap tahun dan juga ada sabagain perusahaan melakukan pencadangan dana untuk kegiatan operasional. Serta sebagian perusahaan juga menggunakan laba yang dihasilkan untuk pengembangan usaha atau ekspansi. Hal inilah yang menyebakan perusahaan tidak membayar dividen setiap tahunya. Salah satunya perusahaan yang tidak membayar dividen bayar dividen setiap tahun adalah memiliki PT. Lippo Cikarang Tbk dan juga memiliki hutang tinggi. Hal tidak sejalan dengan pecking order theory yang menyatakan bahwa perusahaan akan lebih menggunakan dana internal terlebih dahulu untuk membiaya investasi sebelum menggunakan dana eksternal melalui hutang. Dan juga diperkuat dengan hasil penelitian yang dilakukan Sari (2014) yang menyatakan dividend payout ratio tidak berpangaruh signifikan terhadap struktur modal. Namun hal ini tidak sejalan dengan 
penelitian Eviani (2015) yang menyatakan dividend payout ratio memiliki pengaruh terhadap struktur modal. Hal ini disebabkan karena perusahaan yang digunakan dalam penelitian ini berbeda yaitu manufaktur dan tahun penelitian yang digunakan juga berbeda 2011-2013.

\section{KESIMPULAN}

Dari hasil penelitian yang telah dilakukan yang berjudul "Pengaruh Profitabilitas, Likuiditas, Ukuran Perusahaan, Pertumbuhan Penjualan, Dividend Payout Ratio Terhadap Struktur Modal (pada perusahaan Property dan Realestate 2013-2017). Penelitian ini menggunakan metode analisis Regresi Linier Berganda. Berdasarkan hasil analisis data, pengujian, dan pembahasan, maka dapat disimpulkan sebagai berikut:

1. Secara keseluruhan dilihat dari uji $\mathrm{F}$ profitabilitas, likuiditas, ukuran perusahaan, pertumbuhan penjualan, dan dividend payout ratio berpengaruh terhadap struktur modal perusahaan properti dan realestate yang terdaftar di Bursa Efek Indonesia (BEI) pada periode 2013-2017.

2. Secara parsial, profitabilitas tidak berpengaruh terhadap strukrur modal dengan nilai sig 0,104 lebih besar dari 0,025 sehingga $\mathrm{H} 1$ ditolak.

3. Likuiditas berpengaruh terhadap struktur modal dengan nilai sig 0,000 lebih kecil dari 0,025 sehingga $\mathrm{H} 2$ diterima.

4. Ukuran perusahaan tidak berpengaruh terhadap struktur modal dengan nilai sig 0,051 lebih besar dari 0,025 sehingga H3 ditolak.

5. Pertumbuhan penjualan tidak berpangaruh terhadap struktur modal dengan nilai sig 0,269 lebih besar dari 0,025 sehingga H4 ditolak.

6. Dividend payout ratio tidak berpengaruh tidak terhadap struktur modal dengan nilai sig 0,074 lebih besar dari 0,025 sehingga H5 ditolak.

\section{Keterbatasan Penelitian}

Hasil penelitian ini masih memiliki beberapa keterbatasan diantaranya sebagai berikut:

1. Penelitian ini hanya pada perusahaan property dan realestate sehingga tidak ada keberagaman data.

2. Penelitian ini hanya menggunakan rasio-rasio keuangan yang secara umum sering digunakan.

3. Untuk nilai Adjusted R Square adalah sebesar 0,145. Hal ini berarti profitabilitas, likuiditas, ukuran perusahaan, struktur aset, pertumbuhan penjualan, dividend payout ratio berpengaruh $14,5 \%$ terhadap struktur modal dan sisanya $85,5 \%$ dipengaruhi oleh variabel-variabel lain diluar model penelitian.

\section{SARAN}

Berdasarkan hasil penelitian yang telah dijelaskan, maka penulis memberikan saran untuk penelitian selanjutnya:

1. Penelitian selanjutnya dapat memilih sampel penelitian pada sektor lain yang terdaftar di Bursa Efek indonesia.

2. Penelitian selanjutnya, agar menggunakan variabel selain rasio keuangan. 
3. Penelitian selanjutnya, disaran agar meggunakan variabel selain variabel ada pada penelitian ini, karena banyak variabel lain diluar penelitian yang mempengaruhi struktur berdasarkan uji determinas.

\section{REFERENSI}

Atmaja, Setia,Lukas. (2008). Teori dan Pratik Manajemen Keuangan. Penerbit Andi, Yogyakarta.

Ardiana, Agus., dan Adiyana, Sabo, Nicko. (2014). Pengaruh Ukuran Perusahaan, Risiko Bisnis, Pertumbuhan Aset, Profitabilitas dan Likuiditas pada Struktur Modal. E-Jurnal Akuntansi Universitas Udayana.

Brigham, E.F, dan Houston. (2011). Dasar-Dasar Manajemen Keuangan Edisi.1. Jakarta: Erlangga.

Brigham, E.F, dan Houston. (2011). Manajemen Keuangan Edisi Kedelapan Buku 2. Jakarta: Salemba Empat.

Brigham, E.F, Ehrhardt, M.C. (2005). Financial Management Theory And Practice, Eleventh Edition, South Western Cengage Learning, Ohio.

Dewi, Rusmala, Made dan Juliantika,Mas,Amanda, Ayu. (2016). Pengaruh Profitabiitas, Ukuran Perusahaan, Likuiditas, dan Risiko Bisnis terhadap Struktur Modal pada Perusahaan Property dan Realestate. E-jurnal Manajemen Unud.Vol.5,No.7.

Eviani, Dewi, Anantia. (2015). Pengaruh Struktur Aset, Pertumbuhan Penjualan, Dividend Payout Ratio, Likuiditas, dan Profitabilitas terhadap Struktur Modal. Jurnal Akuntansi dan Sistem Teknologi Informasi. Vol.11, No.2.

Fahmi, Irham. (2015). Pengantar Manajemen Keuangan Teori dan Soal jawab. Penerbit Alpabeta, Bandung.

Ghozali, Imam. (2013). Aplikasi Analisis Multivariate dan Program IBM SPSS 21. Edisi 7. Badan Penerbit UNDIP, Semarang.

Hardiningsih, Pancawati, dan Srimindati, Ceacilia. (2017). Pengaruh Struktur Aset Perusahaan terhadap Struktur Modal Dimoderasi Profitabilitas. Jurnal Ilmiah dalam Menyikapi Permenristekdikti RI N0.20.

Joni dan Lina. (2010). Faktor-Faktor yang Mempengaruhi Struktur Modal. Jurnal Bisnis dan Akuntansi. Volume 12, No.12.

Kanita, Ghaida,Ghia. (2014). Pengaruh Struktur Aset terhadap Struktur Modal Perusahaan Makanan dan Minuman. Trikonomika. Vol.13,No.2.

Mustanda, Ketat,I, dan Angelina, Devita, Irriene, Kadek. (2016) . Pengaruh Ukuran Perusahaan, Pertumbuhan Penjualan dan Profitabilitas pada Struktur Modal Perusahaan. E-Jurnal Manajemen Unud, No.5, No.3.

Mamduh M. Hanafi dan Abdul Halim. (2009). Analisis Laporan Keuangan, Edisi Ketiga, YKPN, Yogyakarta.

Riyanto, Bambang. (2011). Dasar-Dasar Pembelanjaan Perusahaan, Edisi keempat, Cetak Ketujuh, BPFE, Yogyakarta. 
Sartono, Agus R. (2010). Manajemen Keuangan Teori dan Aplikasi. Yogyakarta: BPFE, UGM.

Sampurno, Djoko dan Guna, Adi, Michael. (2018). Analisis Faktor-Faktor yang Mempengaruhi Struktur Modal pada Perusahaan Makanan dan Minuman yang terdaftar di BEI (2012-2016). Diponegoro Journal of Management, Volume 7, No.2.

Sari, Pudak, Ayu. (2014). Faktor-Faktor yang Mempengaruhi Struktur Modal pada Perusahaan Non Keuangan yang Terdaftar di BEI (2008-2012). E-Jurnal Akuntansi Universitas Udayana.

Sujarweni, Wiratna,V. (2012). Manajemen Keuangan Teori Aplikasi dan Hasil Penelitian. Pustaka Baru Press.

Widati, Wahyu,L.,dan Farisa, Anggun, Nurul. (2017). Analisis Profitabilitas, Likuiditas, Pertumbuhan Penjualan,Struktur Aset dan Kebijakan dividen terhadap Struktur Modal. Prosiding Seminar Nasional Multi Displin \& Call For Papers.

Wirasedana, Padyantha, W.,dan Abimanyu, Arie, Kharisma,M. (2015). Pengaruh Ukuran Perusahaan, Variabilitas Pendapatan dan Operating Leverage pada Struktur Modal Industri Perbankan. E-Jurnal Akuntansi Unud.

Wiksuana, Bagus,G., dan Krisnanda,Hary. (2015). Pengaruh Ukuran Perusahaan, Pertumbuhan Penjualan dan Non-Debt Tax Shield terhadap Struktur Modal pada Perusahaan Telkomunikasi di BEI. E-Jurnal Manajemen Unud, Vol.4, No.5.

Wasana, Jaka. (2008). Manajemen Keuangan, Edisi Kesembilan, Bina Aksara, Jakarta. www.idx.com diakses pada tanggal 5 Agustus 2018

www. Sahamok.com diakses pada 1 Agustus 2018

www. Kompas.com diakses pada 11 Juli 2018 